\title{
KAEDAH PEMBENTUKAN IDENTITI NASIONAL DALAM UNIVERSITI AWAM DI MALAYSIA
}

\author{
Nur Nadia Lukmanulhakim \\ Jabatan Pengajian Kemasyarakatan dan Kewarganegaraan, \\ Fakulti Sains Kemanusiaan, Universiti Pendidikan Sultan Idris, Tanjong Malim, Perak, Malaysia. \\ nadia.lukman93@gmail.com
}

DOI: https://doi.org/10.37134/peradaban.vol15.1.2020

Received: 18 May 2020; Accepted: 07 October 2020; Published: 28 October 2020

Cite this article (APA): Lukmanulhakim, N. N. (2020). Kaedah Pembentukan Identiti Nasional dalam Universiti Awam di Malaysia. Jurnal Peradaban Melayu, 15, 1-9. https://doi.org/10.37134/peradaban.vol15.1.2020

\begin{abstract}
ABSTRAK
Identiti nasional merupakan komponen penting dalam memupuk perpaduan antara rakyat berbilang kaum di Malaysia. Kajian ini dijalankan bertujuan untuk meneliti kaedah pembentukan identiti nasional di peringkat universiti awam di Malaysia. Sebuah universiti awam telah dipilih daripada 20 buah universiti awam di Malaysia sebagai tempat kajian iaitu Universiti Pendidikan Sultan Idris. Kajian dijalankan melalui kaedah kualitatif dengan temu bual ke atas lima orang pegawai Hal Ehwal Pelajar Universiti Pendidikan Sultan Idris. Dapatan yang diperoleh menunjukkan kaedah pembentukan identiti nasional di universiti awam mencakupi aktiviti akademik, kokurikulum serta sahsiah. Implementasi kaedah pembentukan identiti nasional ini pula mencakupi pelbagai bahagian dalam universiti, melalui program serta kerjasama antara bahagian juga dengan institusi luar. Penambahbaikan ke atas kaedah sedia ada boleh dilakukan dengan mengambil kira keperluan mahasiswa universiti yang terdiri daripada pelbagai budaya.
\end{abstract}

Kata kunci: identiti nasional, pelbagai budaya, universiti awam

\section{PENGENALAN}

Identiti nasional merupakan sebuah komponen penting dalam penyatuan masyarakat dalam sesebuah negara. Identiti nasional didefinisikan sebagai sebuah komuniti yang berkongsi jalur keturunan yang sama (Dahbour, 2002). Perkongsian jalur keturunan yang sama ini membentuk hubungan antara ahli dalam komuniti. Kesan daripada hubungan ini membawa kepada kesedaran berkenaan keunikan mereka sebagai satu komuniti. Identiti nasional berperanan besar dalam mewujudkan rasa kepunyaan sesebuah masyarakat ke atas sesebuah negara.

Pembentukan identiti nasional di negara-negara lain digerakkan dalam pelbagai bentuk. Karya sastera seperti 'Noli Me Tangere' oleh Jose Rizal terhasil daripada kesedaran masyarakat sebagai satu komuniti politik yang digerakkan bagi membentuk sebuah negara. Oleh hal demikian, adalah tidak aneh jika identiti nasional di negara-negara lain wujud terlebih dahulu sebelum kewujudan sesebuah negara. Evolusi gerakan nasionalisme di Vietnam menentang penjajah Perancis adalah atas kesedaran yang terbentuk dalam masyarakat Vietnam (Johnston, 1973). Kesedaran masyarakat Vietnam ini menandakan kewujudan identiti nasional dalam kalangan masyarakat Vietnam sebelum wujudnya negara yang dipanggil 'Vietnam'. Maka, timbul persoalan dalam membezakan gerakan nasionalisme Vietnam dengan gerakan nasionalisme di Tanah Melayu? Gerakan nasionalisme Tanah Melayu berasal daripada kewujudan identiti Melayu. Bukan identiti Tanah Melayu. Provokasi British yang cuba merobek kuasa Raja-Raja Melayu melalui pengisytiharan Malayan Union pada 1946 merupakan satu titik pemula kepada gerakan nasionalisme dalam kalangan orang Melayu. Walau bagaimanapun, gerakan nasionalisme orang Melayu gagal untuk membina negara untuk orang Melayu. Sebaliknya, kumpulan ini memerlukan kerjasama etnik bukan Melayu untuk membentuk sebuah negara (Lukman 
Z, 2001). Justeru, identiti nasional di negara Malaysia masih tidak jelas dan perlu melalui proses pembentukan yang berterusan. Pendidikan merupakan komponen penting dalam pembentukan identiti nasional di Malaysia. Kesedaran berkenaan keperluan pembentukan identiti nasional dalam kalangan rakyat di Malaysia sudah wujud sebelum kemerdekaan Tanah Melayu pada tahun 1957. Penyata Razak yang dilancarkan pada tahun 1956 merupakan usaha pertama kerajaan membentuk satu sistem pendidikan nasional yang memenuhi keperluan pembangunan sosial, budaya, ekonomi dan politik. Penyata ini telah memperincikan beberapa prinsip asas dalam pembentukan sebuah sistem pendidikan nasional ini.

We have also, as required by our terms of reference, taken as a guiding principle the intention to make Malay the national language of the country whilst preserving and sustaining the growth of the languages and culture of non-Malay people living in the country.

(Kementerian Pendidikan Persekutuan Tanah Melayu, 1956)

Prinsip asas pertama yang dinyatakan dalam Penyata Razak adalah berkenaan kedudukan Bahasa Melayu sebagai bahasa kebangsaan Tanah Melayu. Manakala keperluan pemeliharaan dan pengekalan bahasa dan budaya etnik bukan Melayu juga perlu diambil kira.

Oleh hal demikian, prinsip asas kedua yang digariskan dalam Penyata Razak dalah keperluan institusi pendidikan mempunyai sudut pandang Tanah Melayu. Maka, Penyata Razak menyatakan keperluan untuk semua sekolah mempunyai silibus pendidikan yang sama. Hal ini bertujuan untuk memastikan para pelajar berkongsi satu kurikulum, walaupun menggunakan bahasa pengantar berlainan. Prinsip ketiga dalam Penyata Razak pula menekankan objektif utama polisi pendidikan adalah untuk menyatukan kesemua anak-anak tanpa mengira kaum di bawah sistem pendidikan nasional yang menggunakan bahasa kebangsaan sebagai bahasa pengantar.

We believe further that the ultimate objective of educational policy in this country must be to bring together the children of all races under a national education system in which the national language is the main medium of instruction, though we recognise that progress towards this goal cannot be rushed and must be gradual

(Kementerian Pendidikan Persekutuan Tanah Melayu, 1956)

Jelas bahawa prinsip asas dalam perangkaan Penyata Razak adalah untuk menyatukan anak-anak di Tanah Melayu. Prinsip pertama dan kedua menjelaskan bahawa penyatuan dijalankan melalui penggunaan Bahasa Melayu sebagai bahasa kebangsaan di sekolah serta silibus yang sama tanpa mengira bahasa pengantar di sekolah.

Penekanan Penyata Razak kepada penggunaan Bahasa Melayu dalam sistem persekolahan adalah selari dengan prinsip asas pembentukan identiti nasional Malaysia. Dasar Kebudayaan Kebangsaan telah menggariskan tiga prinsip dalam hal pembentukan identiti nasional. Tiga prinsip tersebut adalah; (1) rakyat asal Nusantara sebagai teras kebudayaan (berteraskan kepada kebudayaan rakyat asal rantau), (2) unsur-unsur kebudayaan lain yang sesuai dan wajar diterima melalui penyerapan dan penyesuaian secara berterusan, serta (3) Islam menjadi unsur penting dalam pembentukan kebudayaan kebangsaan (Kementerian Kebudayaan, 1971). Penegasan status Bahasa Melayu sebagai bahasa kebangsaan adalah selaras dengan prinsip pertama yang digariskan dalam Dasar Kebudayaan Kebangsaan.

Penyata Razak dan Dasar Kebudayaan Kebangsaan menggariskan prinsip asas dalam pembentukan identiti nasional di Malaysia. Kaedah pembentukan identiti nasional pula boleh dilihat dalam Dasar Pendidikan Kebangsaan yang menggariskan empat matlamat. Empat matlamat Dasar Pendidikan Kebangsaan ialah melahirkan Bangsa Malaysia yang taat dan bersatu padu, melahirkan insan beriman, berakhlak mulia, berilmu, berketerampilan dan sejahtera, menyediakan sumber tenaga manusia untuk keperluan kemajuan negara dan memberi peluang-peluang pendidikan kepada semua warganegara (Bahagian Perancangan dan Penyelidikan Dasar Pendidikan, 2017). Pelaksanaan empat matlamat ini 
adalah melalui 13 perancangan meliputi kurikulum persekolahan, standard kandungan dan pembelajaran bagi peringkat rendah dan menengah serta peruntukan masa pengajaran dan pembelajaran mengikut kursus pengajian.

Pada peringkat pra sekolah, rendah dan menengah, pembentukan identiti nasional diterapkan melalui penggunaan Bahasa Melayu sebagai bahasa pengantar utama pendidikan berdasarkan peruntukan dalam Akta Pelajaran 1996 (Kerajaan Malaysia, 1997). Kurikulum bersepadu bagi sekolah kebangsaan dan sekolah jenis kebangsaan juga digubal dalam membentuk identiti nasional. Penggubalan kurikulum bersepadu ini penting dalam membentuk pengalaman pembelajaran bersama yang dilalui oleh pelajar dari pelbagai latar budaya di Malaysia. Di peringkat pengajian tinggi, subjek wajib universiti seperti Hubungan Etnik serta Tamadun Islam dan Tamadun Asia (TITAS) merupakan sebahagian daripada kurikulum yang digubal di peringkat pengajian tinggi untuk mencapai tujuan yang sama.

Oleh hal demikian, kajian ini dibuat untuk mengenal pasti kaedah yang digunakan oleh universiti awam bagi membentuk identiti nasional dalam kalangan mahasiswa/inya. Hampir kesemua 13 perancangan yang digariskan oleh Kementerian Pendidikan terpakai dan dihurai secara khusus bagi pendidikan pra sekolah, rendah dan menengah di Malaysia. Kaedah yang khusus digunakan oleh institusi pengajian tinggi, khususnya universiti awam harus diteliti bagi melihat kesinambungan pembentukan identiti nasional dalam sektor pendidikan. Pengajaran dan pembelajaran subjek wajib universiti seperti Hubungan Etnik merupakan contoh kaedah yang digunakan oleh universiti awam dalam skop akademik. Identifikasi kaedah lain yang digunakan oleh universiti awam dapat membantu memberi gambaran lebih menyeluruh berkenaan kaedah pembentukan identiti nasional yang digunakan.

\section{SOROTAN LITERATUR}

Identiti nasional merujuk kepada masyarakat di sesebuah kawasan yang berkongsi sejarah, budaya dan budaya. Identiti nasional merangkumi beberap elemen penting iaitu kawasan yang menjadi tempat masyarakat tersebut rasa kepunyaan, kewujudan satu institusi undang-undang yang sama serta berkongsi nilai dan tradisi (Smith, 1991). Rasa kepunyaan masyarakat terhadap sesuatu tempat membolehkan terbentuknya satu institusi undang-undang yang sah yang mengikat masyarakat tersebut kepada nilai dan tradisi tertentu. Ketiga-tiga elemen ini menandakan kewujudan masyarakat bayangan, atau lebih dikenali sebagai bangsa dalam konsep negara-bangsa.

Oleh hal demikian, identiti nasional merupakan salah satu komponen yang menandakan kewujudan bangsa dalam sesebuah negara. Identiti nasional berfungsi dalam pembentukan identifikasi individu ke atas komponen perlembagaan sesebuah negara menurut tafsiran rakyat negara tersebut sebagai sebuah negara (Cox, Low, \& Robinson, 2008). Ini bermaksud, identiti nasional sesebuah negara adalah berdasarkan tafsiran rakyat negara itu sendiri. Rakyat negara Britain misalnya melihat kemampuan berbahasa Inggeris sebagai ciri penting dalam menentukan identiti nasional British (Kiss \& Park, 2014). Faktor lain seperti kewarganegaraan dan tempat tinggal juga adalah antara ciri-ciri yang digunakan rakyat negara Britain dalam menentukan identiti nasional British seseorang.

Pembentukan identiti nasional di Malaysia berubah daripada acuan mono-etnik kepada acuan multietnik. Kerencaman masyarakat di Malaysia oleh sebab penghijrahan etnik Cina dan India ke Tanah Melayu merubah komposisi penduduk Tanah Melayu. Jumlah populasi etnik India di Tanah Melayu, misalnya, meningkat daripada 239, 200 orang pada 1911 kepada 439, 200 orang pada 1921 (Chander, 1976). Pembentukan Malaysia melalui penggabungan Sabah dan Sarawak dengan Tanah Melayu pula menambahkan lagi kerencaman masyarakat di Malaysia. Kepelbagaian budaya masyarakat Malaysia merupakan salah satu cabaran dalam pembentukan identiti nasional di Malaysia.

Selain itu, globalisasi juga adalah salah satu cabaran dalam membentuk identiti nasional di Malaysia. Hal ini demikian kerana, peningkatan jaringan hubungan masyarakat seluruh dunia melalui teknologi 
telekomunikasi dan pengangkutan telah menyebabkan idea negara-bangsa dianggap tidak lagi relevan. Rana Dasgupta menyebut berkenaan hal ini dalam artikel beliau di The Guardian:

The most momentous development of our era, precisely, is the waning of the nation state; its inability to withstand countervailing 21 st-century forces, and its calamitous loss of influence over human circumstance

(Dasgupta, 2018)

Malah, kajian oleh Lu dan Liu (2018) menunjukkan penghakisan hubungan antara negara dan bangsa berikutan impak daripada teknologi internet. Kajian ini adalah melibatkan responden daripada 33 buah negara melalui kaedah soal selidik yang didapati daripada World Values Survey. Lu dan Liu mendapati penggunaan internet memberikan kesan negatif kepada kepercayaan rakyat kepada kerajaan manakala pembangunan infrastruktur digital menghakis identiti nasional (Lu \& Liu, 2018).

Maka, kerajaan telah menggariskan beberapa langkah dalam pembentukan identiti nasional di peringkat kerajaan. Dalam sektor ekonomi, dasar seperti Dasar Ekonomi Baru (DEB) merupakan antara dasar popular yang digubal kerajaan dengan tujuan perpaduan rakyat Malaysia. Berikutan peristiwa 13 Mei 1969, Dasar Ekonomi Baru (DEB) telah digubal dengan tujuan merapatkan jurang sosioekonomi dalam masyarakat (Aziz, 2012). Walau bagaimanapun, dasar ini telah dilaksanakan dengan pendekatan etnik melalui penetapan kuota ekuiti saham untuk Bumiputera serta kuota kemasukan ke universiti awam berasaskan etnik. Kuota kemasukan ke universiti awam telah dimansuhkan pada tahun 2001.

Pelaksanaan langkah pembentukan identiti nasional yang dijalankan oleh kerajaan jelas bukan sahaja meliputi sektor pendidikan, malah merangkumi sektor ekonomi. Walau bagaimanapun, sejauh mana langkah-langkah ini memberi impak kepada perkembangan pembentukan identiti nasional masih tidak jelas. Kajian lampau berkenaan identiti nasional menunjukkan terdapat tanda-tanda positif berkenaan identiti nasional dalam kalangan masyarakat. Kajian ke atas 800 mahasiswa daripada empat universiti awam menunjukkan bahawa seramai 54.6 peratus memperoleh tahap tinggi dalam konteks jati diri kebangsaan (Othman et al., 2012). Namun, kajian yang sama juga menunjukkan perbezaan signifikan jati diri kebangsaan daripada responden yang berbeza latar belakang etnik. Responden daripada etnik Cina menunjukkan tahap jati diri rendah berbanding etnik Melayu dan India yang berada dalam tahap tinggi. Justeru, kaedah pembentukan identiti nasional baik perlu dicerakinkan dan ditambah baik bagi memenuhi keperluan pelbagai budaya dalam masyarakat Malaysia.

\section{KAEDAH DAN SAMPEL KAJIAN}

Kajian yang bertujuan untuk meneliti kaedah pembentukan identiti nasional yang dijalankan di universiti awam Malaysia ini merupakan sebuah kajian berbentuk eksplorasi. Maka, kajian ini menggunakan pendekatan kualitatif iaitu melalui kaedah temu bual separa berstruktur bagi memenuhi objektif kajian. Sebanyak 20 buah universiti telah dikategorikan sebagai universiti awam di Malaysia. Penyelidik memilih untuk menjalankan kajian di Universiti Pendidikan Sultan Idris, salah sebuah daripada 20 buah universiti awam Malaysia. Pemilihan Universiti Pendidikan Sultan Idris sebagai tempat kajian kerana status universiti tersebut sebagai universiti yang berfokuskan pendidikan.

Pengkhususan temu bual separa berstruktur ke atas pegawai daripada Bahagian Hal Ehwal Pelajar (HEPA) Universiti Pendidikan Sultan Idris (UPSI) adalah sebab penglibatan HEPA dalam perancangan dan pelaksanaan aktiviti pelajar di luar daripada bilik kuliah. Penyelidik menetapkan bahawa pegawai yang terlibat haruslah pegawai yang mempunyai pengalaman bekerja di UPSI sekurang-kurangnya lima tahun, dan bekerja di bahagian HEPA sekurang-kurangnya dua tahun. Ini bagi memastikan pegawai yang ditemu bual sudah menyesuaikan diri dengan suasana pekerjaan di bahagian tersebut. Seramai lima orang pegawai telah di temu bual, meliputi pegawai daripada pelbagai jawatan. Jadual 1 menunjukkan profil responden yang terlibat. 
Jadual 1. Profil Responden Soal Selidik

\begin{tabular}{llcc}
\hline $\begin{array}{l}\text { Nama (bukan } \\
\text { nama sebenar) }\end{array}$ & Bahagian pekerjaan & $\begin{array}{l}\text { Pengalaman bekerja } \\
\text { di UPSI (tahun) }\end{array}$ & $\begin{array}{l}\text { Pengalaman bekerja di } \\
\text { HEPA (tahun) }\end{array}$ \\
\hline Pegawai 1 & Alumni & 19 & 17 \\
\hline Pegawai 2 & Aktiviti Pelajar & 5 & 3 \\
\hline Pegawai 3 & Kolej & 16 & 16 \\
\hline Pegawai 4 & Persatuan Pelajar & 10 & 4 \\
\hline Pegawai 5 & Kolej & 17 & 8 \\
\hline
\end{tabular}

\begin{abstract}
ANALISIS DATA
Temu bual ke atas pegawai HEPA UPSI yang dijalankan menyimpulkan tiga kaedah yang dilaksanakan oleh pihak UPSI dalam pembentukan identiti nasional dalam kalangan mahasiswa. Kaedah pertama dalam pembentukan identiti nasional adalah melalui penggalakan interaksi antara mahasiswa dalam universiti. Bahagian HEPA menjalankan kaedah ini melalui perkongsian ruang dan aktiviti antara mahasiswa pelbagai budaya. Pegawai 5 menyatakan bahawa program yang dijalankan bersifat terbuka dan tidak tertumpu kepada mana-mana etnik.

Bahagian HEP universiti memantau program-program yang dijalankan dalam universiti. Sama ada program tersebut dianjurkan oleh pelajar atau pengurusan universiti, setiap program perlu melibatkan pelajar daripada pelbagai kaum. Tiada program yang dibuat khusus kepada satu-satu etnik sahaja
\end{abstract}

(Pegawai 5, 21 Jun 2018)

Pegawai 5 menegaskan bahawa langkah yang diambil ini adalah untuk mengekalkan keharmonian antara mahasiswa pelbagai budaya dalam universiti. Perkongsian ruang dan aktiviti antara mahasiswa pelbagai budaya di universiti juga disebut oleh Pegawai 3. Pegawai 3 menyebut berkenaan polisi perkongsian ruang yang dilaksanakan oleh kolej kediaman di UPSI.

Dasar Kementerian Pendidikan telah pun menekankan berkenaan integrasi kaum. Antara kaedah yang dijalankan adalah melalui percampuran, negeri, bangsa, dalam satu rumah

(Pegawai 3, 11 Jun 2018)

Pegawai 3 menjelaskan bahawa polisi yang dilaksanakan UPSI ini merupakan dasar yang ditetapkan oleh Kementerian Pengajian Tinggi. Dasar ini ditetapkan bagi memastikan integrasi antara mahasiswa pelbagai budaya dalam universiti dapat berlaku. Langkah perkongsian ruang atau aktiviti ini merupakan salah satu kaedah dalam menggalakkan interaksi antara mahasiswa pelbagai budaya.

Kaedah kedua yang dijalankan oleh UPSI adalah melalui pelaksanaan program kebudayaan dan patriotisme. Dalam bahagian Hal Ehwal Pelajar (HEPA), pelaksanaan program kebudayaan dan patriotisme di universiti dirancang dan dilaksanakan oleh dua pihak. Penganjur program biasanya terdiri daripada pihak pentadbiran universiti ataupun daripada usaha mahasiswa UPSI sendiri iaitu melalui persatuan-persatuan pelajar. Penganjuran program kebudayaan oleh pihak pentadbiran universiti diterajui oleh Pusat Kebudayaan UPSI dan Kolej Kediaman. Hal ini disebut oleh Pegawai 4 dalam temu bual bersama beliau.

Pusat Kebudayaan, Kolej Kediaman dan kadangkala fakulti adalah antara entiti dalam universiti yang selalu menganjurkan program-program kebudayaan dalam universiti. 
Penganjuran program kebudayaan UPSI bukan sahaja melibatkan dua bahagian ini, malah turut melibatkan kolaborasi dengan pihak luar seperti Istana Budaya.

Program seperti bengkel asas gamelan dan bengkel tarian tradisional juga diadakan oleh Pusat Kebudayaan UPSI. Selain itu, terdapat juga program lain seperti Lawatan Silang Budaya dan program berbentuk kolaborasi dengan Istana Budaya.

(Pegawai 4, 3 Julai 2018)

Manakala bagi program patriotisme, terdapat penganjuran program patriotisme yang melibatkan masyarakat sekitar. Hal ini disebut oleh Pegawai 2 dalam temu bual bersama beliau.

Banyak program yang telah diadakan oleh universiti dalam usaha untuk memupuk budaya nasional. Antaranya ialah program patriotisme sempena tarikh 31 Ogos, program kerjasama dengan masyarakat berdekatan, mencakupi sehingga ke kawasan Slim River.

(Pegawai 2, 6 Julai 2018)

Penganjuran program patriotisme di UPSI tidak terhad kepada penganjuran di peringkat universiti dan melibatkan masyarakat sekitar sahaja. Malah, terdapat juga program patriotisme yang dianjurkan di peringkat yang lebih kecil seperti di fakulti masing-masing.

Dua kaedah yang dijalankan oleh HEPA UPSI ini juga dijalankan oleh bahagian lain dalam universiti, seperti bahagian Akademik UPSI. Sebagai contoh, perkongsian ruang dan program antara mahasiswa berlainan budaya diterapkan dalam program akademik. Kaedah ini melibatkan penyusunan kedudukan mahasiswa dalam ruang kuliah, sebagai contoh yang diberikan oleh Pegawai 1.

Tenaga pengajar itu sendiri perlu memisahkan pelajar yang selalu duduk bersama dalam kumpulan mereka di dalam kelas. Walaupun dianggap sebagai perkara kecil, langkah sebegini perlu dilakukan.

(Pegawai 1, 12 Jun 2018)

Kaedah ini digunakan oleh pegawai yang terlibat dalam program akademik bagi memastikan mahasiswa tidak terlalu bergantung pada mahasiswa dalam kumpulan budaya yang sama. Oleh hal demikian, pemecahan pelajar kepada kumpulan yang luar daripada kebiasaan mereka dapat membantu dalam menggalakkan interaksi antara mahasiswa pelbagai budaya di UPSI.

Penglibatan jabatan lain dalam hal pembentukan identiti nasional juga tidak terhad kepada perkongsian ruang, malah turut melibatkan penganjuran program di peringkat fakulti. Program bersifat kebudayaan dan patriotisme, kadangkala dianjurkan oleh pihak fakulti sendiri bagi menjayakan agenda pembentukan identiti nasional. Subjek kenegaraan merupakan salah satu program patriostime berbentuk akademik yang dijayakan oleh bahagian akademik. Temu bual bersama Pegawai 4 menyebut berkenaan perkara ini.

Aktiviti kenegaraan di universiti ini dilihat sangat kurang. Antara program kenegaraan yang ada ialah subjek kenegaraan yang diambil di fakulti.

Terdapat juga senario program kebudayaan juga dianjurkan di peringkat fakulti. Perkara ini juga disebut oleh Pegawai 4 ketika menyebut berkenaan Pusat Kebudayaan UPSI dan Kolej bagi penganjuran program kebudayaan. 
Bagi pihak pentadbiran tertinggi UPSI, kaedah lain yang ditetapkan bagi pembentukan identiti nasional adalah program AA iaitu penekanan kepada keseimbangan komponen akhlak dan akademik bagi setiap mahasiswa. Program ini diterajui oleh Naib Canselor UPSI yang kemudiannya dilaksanakan oleh setiap jabatan dalam universiti. Perkara ini disebut dalam temu bual bersama Pegawai 2.

Program 'double' A di UPSI diterajui oleh Naib Canselor sendiri. 'Double' A merujuk kepada akademik dan akhlak. Program ini kemudiannya diturunkan kepada bahagian Akademik dan Hal Ehwal Pelajar untuk ditafsirkan.

(Pegawai 2, 6 Julai 2018)

Penekanan UPSI kepada kecemerlangan dalam kedua-dua aspek iaitu akademik dan akhlak dilihat perlu dalam membentuk identiti nasional dalam kalangan mahasiswa UPSI.

Selain kaedah dan pendekatan yang telah dibincangkan dalam pembentukan identiti nasional di atas, beberapa syarat juga telah ditetapkan dalam memastikan keharmonian antara masyarakat pelbagai budaya di UPSI dapat sentiasa dipelihara. Antara syarat tersebut adalah larangan penubuhan persatuan berasaskan etnik dan agama. Sebaliknya, kelonggaran dibenarkan bagi penubuhan persatuan bagi elemen budaya lain seperti bahasa. Perkara ini dijelaskan oleh Pegawai 4.

Penubuhan persatuan berasaskan etnik dan agama adalah tidak dibenarkan. Walau bagaimanapun, terdapat persatuan seperti Persatuan Al-Mursyidin dan PERKIM di UPSI yang menjalankan pelbagai aktiviti untuk pelajar Muslim.

(Pegawai 4, 3 Julai 2018)

Syarat ini adalah bagi memastikan tidak wujud perpecahan dalam kalangan mahasiswa yang melibatkan etnik dan agama. Penubuhan persatuan berasaskan bahasa disifatkan oleh Pegawai 4, bersifat lebih terbuka dan dapat diikuti oleh mahasiswa yang berminat untuk mempelajari bahasa tersebut. Syarat ini juga terpakai bagi penganjuran aktiviti dalam kalangan mahasiswa, terutama dalam kalangan jawatankuasa program. Percampuran dalam kalangan mahasiswa pelbagai etnik ditekankan oleh pegawai HEPA dalam usaha menggalakkan interaksi antara mahasiswa.

Kepelbagaian etnik dalam Majlis Mahasiswa Kolej (MMK) boleh dilihat melalui ahli MMK serta program yang dianjurkan. Malah, dalam persatuan lain seperti persatuan anak negeri, bahasa, dan debat juga banyak percampuran etnik.

(Pegawai 3, 11 Jun 2018)

Menurut pegawai yang ditemu bual, jika perlu, pegawai akan meminta supaya dibuat percampuran dan perpaduan antara kaum dan budaya jika jawatankuasa program atau persatuan dilihat cenderung ke arah satu kumpulan budaya tertentu.

Jelas bahawa kaedah dan perancangan dalam pembentukan identiti nasional yang ditetapkan di UPSI adalah melibatkan kaedah yang dilaksanakan di pelbagai peringkat, melibatkan pelbagai jabatan dalam universiti. Pendekatan ini adalah untuk memastikan kaedah yang telah ditetapkan adalah bersifat menyeluruh dan dapat dilaksanakan dalam setiap aspek kehidupan mahasiswa di universiti. Kolaborasi dan koordinasi antara jabatan di universiti adalah penting bagi memastikan kaedah dan perancangan dapat dilaksanakan dengan teratur. 


\section{KESIMPULAN}

Pihak Universiti Pendidikan Sultan Idris (UPSI) mengambil pendekatan yang menyeluruh dalam usaha pembentukan identiti nasional. Setiap jabatan dan bahagian memainkan peranan penting dalam melaksanakan kaedah dan perancangan yang telah ditetapkan. Kerjasama antara bahagian juga dibentuk bagi menjalankan sesetengah program untuk dijalankan di setiap bahagian. Kerjasama antara bahagian ini adalah penting bagi memastikan perancangan dan kaedah yang telah dirangka dapat dilaksanakan dalam setiap aspek kehidupan mahasiswa di universiti. Kebanyakan perancangan dan kaedah yang dijalankan oleh pihak universiti adalah berbentuk pendekatan atas-bawah (top-bottom). Hal ini bermaksud peringkat perancangan adalah melibatkan pihak pentadbiran universiti atau bahagian yang kemudiannya dilaksanakan oleh staf universiti dengan kerjasama mahasiswa.

Penambahbaikan dalam kaedah dan perancangan sedia ada boleh dilakukan melalui pendekatan bawahatas (bottom-up). Ini dapat dilakukan melalui galakkan penglibatan mahasiswa dalam lebih banyak program dan kaedah sedia ada. Selain daripada dapat memupuk kesedaran dalam kalangan mahasiswa akan kepentingan identiti nasional, pendekatan ini juga dapat memberi ruang kepada mahasiswa sendiri untuk menjayakan agenda universiti dan negara. Bukan itu sahaja, dialog serta ruang untuk mahasiswa memberi pandangan dan idea juga boleh diadakan bagi melibatkan mahasiswa pada peringkat perancangan. Peningkatan penglibatan mahasiswa dalam kedua-dua proses perancangan dan pelaksanaan dapat meningkatkan kefahaman mahasiswa berkenaan identiti nasional. Pendekatan bawah-atas dalam pembentukan identiti nasional ini juga dapat memberi ruang kepada mahasiswa daripada latar belakang kumpulan minoriti untuk menyuarakan pendapat mereka. Sekali gus, hal ini membantu menjayakan pelaksanaan kaedah pembentukan identiti nasional yang menepati keperluan kepelbagaian budaya masyarakat di Malaysia.

Penyelidik berharap kajian ini dapat memberi sedikit sumbangan dalam membina kefahaman berkenaan identiti nasional serta pembentukannya di peringkat pengajian tinggi. Walau bagaimanapun, harus diingat bahawa kajian ini terhad kepada dapatan daripada salah satu universiti awam daripada 20 buah universiti awam yang ada di Malaysia. Maka, kajian ini tidak mewakili kesemua universiti awam di Malaysia. Kajian lanjut ke atas semua universiti awam dan universiti swasta adalah perlu bagi melihat perancangan dan kaedah yang dilaksanakan bagi setiap institusi. Dapatan kajian ini diharap dapat menjadi langkah pertama bagi membina kesinambungan pembentukan identiti nasional di peringkat pengajian tinggi.

\section{RUJUKAN}

Aziz, R. A. (2012). New Economic Policy and the Malaysian multiethnic middle class. Asian Ethnicity, 13(1), $29-46$. https://doi.org/10.1080/14631369.2012.625692

Bahagian Perancangan dan Penyelidikan Dasar Pendidikan. (2017). Dasar Pendidikan Kebangsaan. dalam Kementerian Pendidikan Malaysia. https://doi.org/10.1017/CBO9781107415324.004

Chander, R. (1976). 1970 General Report: Population Census of Malaysia. Kuala Lumpur.

Cox, K. R., Low, M., \& Robinson, J. (2008). The SAGE handbook of political geography. dalam The SAGE Handbook of Political Geography. https://doi.org/10.4135/9781848607880

Dahbour, O. (2002). National Identity: An Argument for the Strict Definition. Public Affairs Quarterly, 16(1), 17-37. dipetik daripada https://www.jstor.org/stable/40441311?seq=3\#page_scan_tab_contents 
Dasgupta, R. (2018, April). The demise of the nation-state. The Guardian. dipetik daripada https://www.theguardian.com/news/2018/apr/05/demise-of-the-nation-state-rana-dasgupta

Johnston, E. J. (1973). Evolution of Vietnamese nationalism. Universiti Montana.

Kementerian Kebudayaan, K. dan P. (1971). Dasar Kebudayaan Kebangsaan. In Pejabat Perdana Menteri Malaysia. dipetik daripada http://www.pmo.gov.my/dokumenattached/_Dasar/04Dasar_Kebudayaan_Kebangsaan.pdf

Kementerian Pendidikan Persekutuan Tanah Melayu. (1956). Laporan Jawatankuasa Pelajaran 1956. Kuala Lumpur.

Kerajaan Malaysia. Akta Pendidikan 1996. (1997).

Kiss, Z., \& Park, A. (2014). National identity: Exploring Britishness. dalam British Social Attitudes: the 31st Report. London.

Lu, J., \& Liu, X. (2018). The Nation-State in the Digital Age: A Contextual Analysis in 33 Countries. International Journal of Communication, 12, 21.

Lukman Z, M. (2001). Transformasi Bentuk Bangsa Malaysia dan Identiti Nasional. International Malaysia Studies Conference. Bangi.

Othman, M. Y., Dakir, J., Samian, A. L., Hasim, M. S., M Awal, N. A., Yahya, S. A., .. A Bakar, M. (2012). Jati diri kebangsaan dalam kalangan pelajar institusi pengajian tinggi. Jurnal Hadhari, 4, 67-78.

Smith, A. (1991). National Identity. London: Penguin Books. 